\title{
PENGARUH FAKTOR INTERNAL DAN EKSTERNAL TERHADAP PERTUMBUHAN LABA PADA BANK UMUM SWASTA NASIONAL (BUSN) NON DEVISA PERIODE 2014-2018
}

\author{
Andini Estikarti Utami \\ Universitas Negeri Surabaya \\ Email: andiniutami16080574128@mhs.unesa.ac.id
}

\begin{abstract}
Banks in Indonesia are required to do their own assessment by using a risk-based bank rating based on RGECRisk Profile, GCG, Earnings, and Capital. The goal of this research is to analyze the leverage of internal and external factors on the profit growth of non-foreign exchange national private commercial banks in 2014-2018. This research is a causal study with purposive sampling technique, so that 21 banks sample are obtained. The analysis method used in this research is multiple linear regression analysis. In this study, it was found that there was a simultaneous influence between the independent variables on profit growth. Partially, only LDR has a positive and significant effect on profit growth. When LDR ratio increases, profit growth will also increase which means that operational activities have been running efficiently and the bank can fulfill its obligations to creditors. Meanwhile, the other variables such as NPL, GCG, ROA, BOPO, CAR, and inflation do not affect on profit growth.
\end{abstract}

Keywords: bank; internal \& external factors; profit growth; RGEC.

\section{PENDAHULUAN}

Eksistensi bank berperan penting untuk mendorong perekonomian suatu negara. Saat ini peran perbankan tidak dapat dipisahkan dari kehidupan masyarakat. Melalui berbagai jasa-jasa yang diberikan oleh bank, masyarakat dapat melakukan transaksi dengan aman dan mudah menjadikan perbankan semakin diminati. Sebagai lembaga yang berperan dalam fungsi mediasi, perbankan perlu menjaga kinerja keuangan tetap sehat supaya fungsi tersebut dapat beroperasi secara optimal. Jika perbankan dapat mengoptimalkan pertumbuhan laba dengan menjaga tingkat kesehatannya, maka akan berdampak pada stabilitas sistem keuangan di Indonesia. Oleh karena itu, perbankan wajib melaksanakan penilaian sendiri (self assessment) berdasarkan ketentuan Bank Indonesia yang menerbitkan Surat Edaran tentang Penilaian Tingkat Kesehatan Bank Umum pada tahun 2011 dengan cara pendekatan risiko (Risk Based Bank Rating) (Akhyar et al., 2018). Menurut Surat Edaran Bank Indonesia No.13/24/DPNP/2011, penilaian tingkat kesehatan bank memiliki beberapa faktor dengan istilah RGEC yang terdiri dari Risk profile (profil risiko), GCG (Good Corporate Governance), Earnings (rentabilitas), dan Capital (permodalan).

Menurut Anggraeni (2013), laba diperoleh dari seluruh transaksi dalam perusahaan dan akan berdampak pada kegiatan operasional di kurun waktu tertentu melalui selisih antara pendapatan dengan beban. Jika pendapatan yang diterima lebih banyak dibandingkan beban yang ditanggung, hal ini mengindikasikan perbankan akan meraih laba. Sementara, perbankan akan mengalami kerugian apabila terjadi hal yang sebaliknya. Memperoleh laba merupakan tujuan yang ingin dicapai setiap perusahaan termasuk perbankan. Mursyidan \& Hanantijo (2016) mengemukakan bahwa pertumbuhan laba menjadi indikator penting untuk mengukur berhasil tidaknya suatu perbankan dalam melaksanakan kegiatan usahanya dan mengindikasikan pihak manajemen secara efektif dan efisien telah mengelola sumber daya yang dimilikinya. Informasi mengenai pertumbuhan laba yang tercermin dalam laporan keuangan dapat dijadikan sebagai proses pengambilan keputusan dan pertimbangan prospek suatu perusahaan di masa mendatang bagi pihak yang memiliki kepentingan. 
Andini Estikarti Utami. Pengaruh Faktor Internal dan Eksternal terhadap Pertumbuhan Laba pada Bank Umum Swasta Nasional (BUSN) Non Devisa Periode 2014-2018.

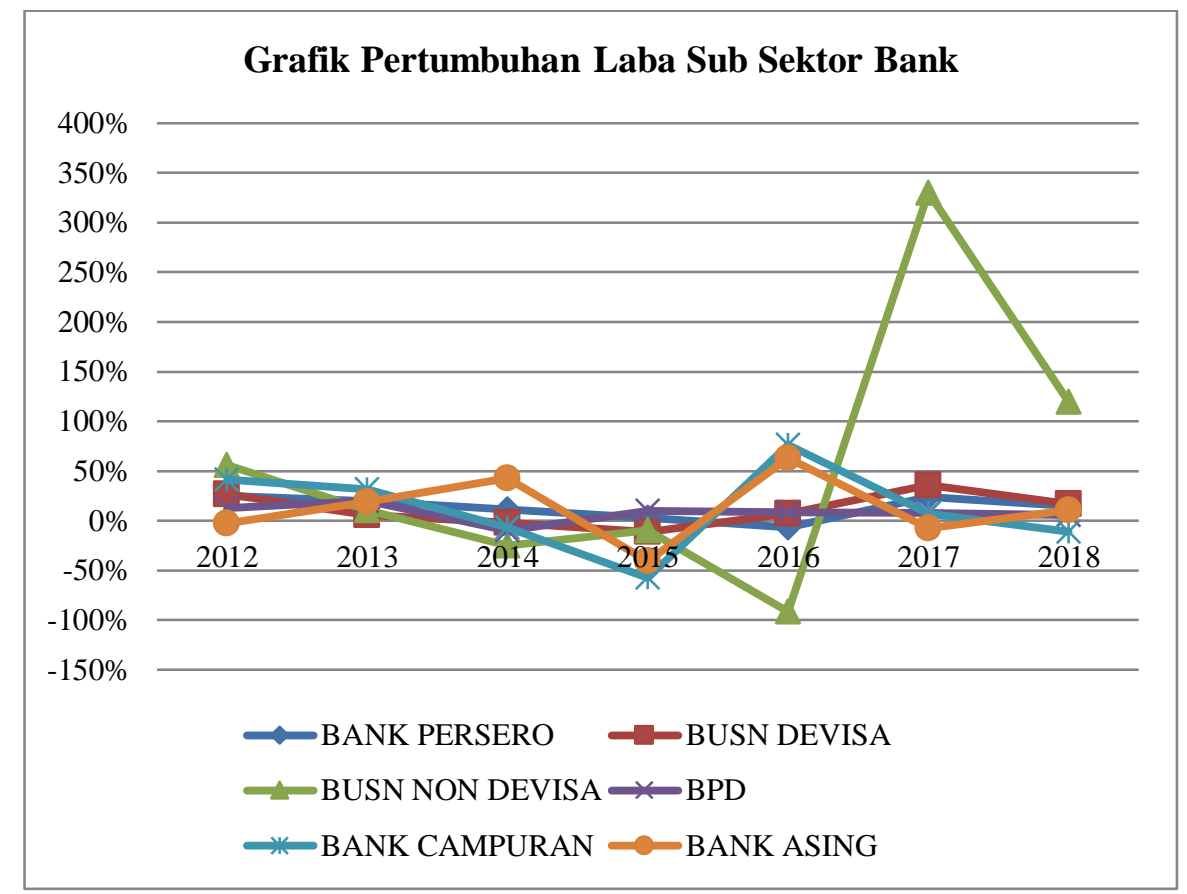

\section{Sumber: Statistik Perbankan Indonesia (data diolah, 2019) \\ Gambar 1. GRAFIK PERGERAKAN PERTUMBUHAN LABA SUB SEKTOR BANK TAHUN 2012-2018}

Mengacu dari data Statistik Perbankan Indonesia tahun 2012-2018, pergerakan pertumbuhan laba sub sektor perbankan selama periode 2012-2018 tercermin dalam gambar 1. Pertumbuhan laba BUSN non devisa di tahun 2012 senilai 56\%, kemudian menurun pada tahun 2013 dan 2014 sebesar $10 \%$ dan $25 \%$, sementara peningkatan pertumbuhan laba terjadi di tahun 2015 menjadi $-10 \%$, untuk tahun 2016 pertumbuhan laba mendapati penurunan yang sangat signifikan sebesar $-91,60 \%$, akan tetapi terjadi peningkatan yang tajam pada tahun 2017 menjadi 330\%, dan pada tahun 2018 menurun kembali sebesar $120 \%$.

Berdasarkan enam sub sektor bank, hanya BUSN non devisa dan BPD yang tidak mengalami penurunan pertumbuhan laba di tahun 2015 meskipun tidak terlalu signifikan. Namun, pada tahun tersebut menurut Diah (2016) laba perbankan di tahun 2015 mengalami penurunan dibandingkan tahun 2014 dikarenakan kondisi perekonomian global maupun nasional yang kurang menguntungkan sehingga perbankan lebih berhati-hati dalam menjalankan bisnisnya dengan membentuk CKPN (Cadangan Kerugian Penurunan Nilai) seiring meningkatnya rasio kredit bermasalah.

Pada gambar 1, BUSN non devisa mengalami penurunan pertumbuhan laba yang tajam dibandingkan dengan bank lain di tahun 2016 senilai $-92 \%$. Menurut banten.bisnis.com, hal ini dapat terjadi karena adanya penyaluran kredit yang lambat dari tahun lalu sebesar 4,66\% dan besarnya pencadangan dana berupa CKPN (Cadangan Kerugian Penurunan Nilai) untuk mengantisipasi kenaikan rasio kredit akibat perlambatan ekonomi. Di tahun 2017 sektor keuangan memperoleh laba bersih paling besar dibandingkan sektor lainnya senilai Rp 115,98 triliun dengan perolehan rata-rata pertumbuhan laba bersih sebesar 5,42\% (Jatmiko, 2018). Hal ini selaras dengan adanya kontribusi sub sektor bank yang dapat dilihat melalui pertumbuhan laba BUSN non devisa mengalami kenaikan yang signifikan dibandingkan bank-bank lain, padahal BUSN non devisa dalam kegiatan operasionalnya hanya mencatat transaksi berupa mata uang resmi Indonesia dalam bentuk rupiah dan tidak melalukan pencatatan transaksi dalam bentuk mata uang asing (Fahmi, 2015:7).

Dengan adanya fenomena tersebut, BUSN non devisa digunakan sebagai objek dalam penelitian ini. Rentang waktu yang dipakai adalah 5 tahun selama periode 2014-2018 dikarenakan penurunan pertumbuhan laba pertama kali dialami BUSN non devisa di tahun 2014 dan ketersediaan laporan keuangan terbaru ada pada 2018 yang menjadikan tahun tersebut sebagai periode terakhir. Tujuan dari 
penelitian yang dilakukan yaitu mengkaji faktor internal dan eksternal yang mempengaruhi pertumbuhan laba. Adapun faktor internal yang diproksikan dengan RGEC antara lain NPL (Non Performing Loan), LDR (Loan to Deposit Ratio), GCG (Good Corporate Governance), ROA (Return On Asset), BOPO (Biaya Operasional Pendapatan Operasional), CAR (Capital Adequacy Ratio) serta faktor eksternal yang diproksikan oleh inflasi.

\section{KAJIAN PUSTAKA DAN PENGEMBANGAN HIPOTESIS}

\section{Teori Sinyal (Signaling Theory)}

Teori sinyal dikemukakan oleh Michael Spence pertama kali pada tahun 1973 bahwa pihak manajemen sebagai pemberi sinyal dan stakeholder sebagai penerima sinyal. Pihak manajemen akan memberikan informasi yang relevan sehingga stakeholder dapat memanfaatkan informasi dan mengambil keputusan yang tepat sesuai dengan pemahamannya akan sinyal tersebut. Investor mencari tanda-tanda kinerja, peluang, atau kelemahan melalui sinyal untuk mendapatkan informasi yang nantinya digunakan sebagai pertimbangan pengambilan keputusan (Gumanti, 2017:249). Menurut Mursyidan \& Hanantijo (2016), pergerakan pertumbuhan laba dapat ditandai melalui laporan keuangan dengan adanya sinyal baik (good news) maupun sinyal buruk (bad news).

\section{Teori Keagenan (Agency Theory)}

Teori ini dipublikasikan oleh Jensen dan Meckling di tahun 1976 karena dalam hubungan keagenan dapat terjadi konflik agensi, sehingga adanya agency theory ditujukan untuk menangani perselisihan tersebut. Agency problems dapat terjadi apabila manajer tidak lagi bertindak untuk kepentingan pemilik (Gumanti, 2017:245). Hanafi \& Breliastiti (2016) menyatakan dalam teori keagenan terdapat pemisahan antara pemilik (principal) dan pengelola perusahaan (agent) yang memiliki kepentingannya masing-masing sehingga terjadi konflik kepentingan antara principal dan agent. Agency theory dalam penelitian ini digunakan untuk meneliti hubungan dari GCG (Good Corporate Governance).

\section{Pertumbuhan Laba}

Terdapat beberapa indikator bagi perbankan untuk menilai kinerja pada kurun waktu tertentu, satu diantaranya adalah dengan melihat pertumbuhan laba melalui laporan keuangan. Semakin besar laba yang didapat menandakan bahwa kinerja manajemen bank tersebut juga semakin baik (Suryani \& Habibie, 2017). Dalam penelitiannya, Irma et al. (2016) menyatakan bahwa pertumbuhan laba yaitu pertumbuhan relatif yang dapat dihitung dengan cara mengurangi laba bersih tahun berjalan dan tahun sebelumnya dibagi dengan laba bersih tahun sebelumnya. Pertumbuhan laba yang meningkat mengindikasikan bahwa perusahaan telah melakukan kinerjanya dengan baik. Berikut adalah perhitungan untuk mengukur pertumbuhan laba (1) menurut Irma et al. (2016).

Pertumbuhan laba $=\frac{\text { Laba bersih tahun } t-\text { Laba bersih } \operatorname{tahun}(t-1)}{\text { Laba bersih } \operatorname{tahun}(t-1)}$

\section{Non Performing Loan (NPL)}

Perbankan dalam menjalankan kegiatan operasionalnya memiliki berbagai macam risiko, satu diantaranya adalah risiko kredit yang merupakan risiko terhadap besarnya penyaluran kredit kepada nasabah. Apabila jumlah kredit yang disalurkan semakin besar, maka risiko kredit juga akan meningkat (Purwoko \& Sudiyatno, 2013). Dalam penelitian ini risiko kredit diproksikan dengan NPL yaitu kredit macet atau kredit yang bermasalah. Berikut adalah rumus dari NPL (2) dalam Lampiran SE BI No. 13/24/DPNP/2011.

$N P L=\frac{\text { Kredit bermasalah }}{\text { Total kredit }} \times 100 \%$

\section{Loan to Deposit Ratio (LDR)}

Alfin \& Hartono (2018) dalam penelitiannya mengungkapkan bahwa LDR dapat mengindikasikan kesanggupan perbankan dalam membayar kembali penarikan oleh nasabah dengan mengutamakan 
Andini Estikarti Utami. Pengaruh Faktor Internal dan Eksternal terhadap Pertumbuhan Laba pada Bank Umum Swasta Nasional (BUSN) Non Devisa Periode 2014-2018.

sumber likuiditas dari penyaluran kredit. Maka dari itu, LDR berperan penting dalam menilai apakah fungsi bank sebagai lembaga mediasi sudah berjalan dengan baik atau belum. Mengacu pada Surat Edaran Bank Indonesia Nomor 3/30/DPNP tanggal 14 Desember 2001, perhitungan LDR (3) adalah sebagai berikut.

$L D R=\frac{\text { Total Kredit }}{\text { Dana Pihak Ketiga }} \times 100 \%$

\section{Good Corporate Governance (GCG)}

Penerapan tata kelola bank pada seluruh jenjang organisasi dikenal dengan istilah Good Corporate Governance (GCG). Dalam penelitian ini, GCG dihitung dengan nilai komposit dari self assesment sebagaimana telah ditetapkan dalam SE BI No. 15/15/DPNP tanggal 29 April 2013. Pracoyo \& Putriyanti (2016) menyatakan apabila nilai komposit yang diperoleh suatu bank itu kecil, maka kualitas manajemen bank baik dan diikuti oleh peningkatan laba. Nilai komposit diperoleh dari hasil perkalian bobot persentase dengan peringkat (interval 1-5) dan menjumlahkan nilai akhir dari 11 (sebelas) faktor tersebut seperti dalam tabel 1 di bawah ini.

Tabel 1.

PERHITUNGAN NILAI KOMPOSIT SELF ASSESMENT GCG

\begin{tabular}{|c|c|c|c|}
\hline Faktor & Bobot & Peringkat & Nilai \\
\hline Pelaksanaan tugas dan tanggung jawab Dewan Komisaris & $10 \%$ & 0 & 0 \\
\hline Pelaksanaan tugas dan tanggung jawab Direksi & $20 \%$ & 0 & 0 \\
\hline Kelengkapan dan pelaksanaan tugas Komite & $10 \%$ & 0 & 0 \\
\hline Penanganan benturan kepentingan & $10 \%$ & 0 & 0 \\
\hline Penerapan fungsi kepatuhan Bank & $5 \%$ & 0 & 0 \\
\hline Penerapan fungsi audit intern & $5 \%$ & 0 & 0 \\
\hline Penerapan fungsi audit ekstern & $5 \%$ & 0 & 0 \\
\hline $\begin{array}{l}\text { Fungsi manajemen risiko termasuk sistem pengendalian } \\
\text { intern }\end{array}$ & $7,5 \%$ & 0 & 0 \\
\hline $\begin{array}{l}\text { Penyediaan dana kepada pihak terkait (related party) dan } \\
\text { debitur besar (large exposures) }\end{array}$ & $7,5 \%$ & 0 & 0 \\
\hline $\begin{array}{l}\text { Transparansi kondisi keuangan dan non keuangan, laporan } \\
\text { pelaksanaan Good Corporate Governance } \\
\text { dan pelaporan internal }\end{array}$ & $15 \%$ & 0 & 0 \\
\hline Rencana strategis Bank & $5 \%$ & 0 & 0 \\
\hline Nilai Komposit & $100 \%$ & & 0 \\
\hline
\end{tabular}

\section{Return On Assets (ROA)}

Dalam faktor earnings, perbankan dapat menggunakan ROA untuk mengetahui seberapa besar penanaman investasi dapat menghasilkan laba sesuai harapan (Widyaningrum, 2014). Menurut Lampiran SE BI No. 13/24/DPNP/2011, ROA (4) dapat dihitung menggunakan rumus di bawah ini.

$R O A=\frac{\text { Laba sebelum pajak }}{\text { Rata-rata total aset }} \times 100 \%$

\section{Biaya Operasional Pendapatan Operasional (BOPO)}

Guna mengukur seberapa mampu perbankan mengelola biaya operasional yang ditanggung terhadap pendapatan operasional yang diperoleh dapat digunakan rasio efisiensi. Dalam hal ini, jika rasio ini memiliki nilai yang kecil artinya biaya operasional yang digunakan perbankan semakin efisien (Lubis, 2013). Rasio BOPO (5) dapat dihitung menggunakan rumus di bawah ini mengacu pada Surat Edaran Bank Indonesia Nomor 3/30/DPNP tanggal 14 Desember 2001.

BOPO $=\frac{\text { Total beban operasional }}{\text { Total pendapatan operasional }} \times 100 \%$ 


\section{Capital Adequacy Ratio (CAR)}

Lubis (2013) mengungkapkan bahwa rasio CAR dapat digunakan untuk mengukur kecukupan modal perbankan guna pengembangan usaha dan mengantisipasi terjadinya risiko kerugian dalam kegiatan operasional bank. Cara menghitung CAR (6) bersumber dari Lampiran SE BI No. 13/24/DPNP/2011 adalah sebagai berikut.

$C A R=\frac{\text { Modal }}{\text { Aktiva Tertimbang Menurut Risiko }} \times 100 \%$

\section{Inflasi}

Sukirno (2011:14) dalam bukunya menjelaskan bahwa inflasi ialah proses naiknya harga-harga secara meluas yang terjadi pada perekeonimian di suatu negara. Inflasi juga dapat terjadi pada saat permintaan akan barang-barang tidak seimbang dengan persediaannya. Penelitian ini menggunakan data inflasi tahunan yang dapat dinyatakan dengan rumus (7) sebagai berikut (Mursyidan \& Hanantijo, 2016).

Inflasi $=$ Indeks Harga Konsumen tahun ke $-\mathrm{n}$.

\section{Hubungan Antar Variabel}

Jika penyaluran kredit mengalami kemacetan, maka kemampuan penyaluran kredit oleh bank kepada kreditur lain akan menurun. Kondisi ini dapat berdampak pada kerugian bank yang diindikasikan dengan penurunan pertumbuhan laba (Uran \& Wuryani, 2019).

H1: Ada pengaruh dari risk profile yang diproksikan dengan NPL (Non Performing Loan) terhadap pertumbuhan laba.

Krisnawati \& Chabachib (2014) mengemukakan jika bank melakukan pembiayaan dalam bentuk kredit, maka rasio LDR akan ikut meningkat. Dampaknya bank meraih kenaikan pertumbuhan laba yang didapat dari bunga kredit.

H2: Ada pengaruh dari risk profile yang diproksikan dengan LDR (Loan to Deposit Ratio) terhadap pertumbuhan laba.

Bank wajib melakukan self assessment untuk mengukur GCG dengan menggunakan nilai komposit. Semakin rendah nilai komposit GCG yang diperoleh bank, artinya tata kelola perbankan sangat baik sehingga dapat mendukung bank dalam meraih pertumbuhan laba (Mursyidan \& Hanantijo, 2016).

H3: Ada pengaruh dari GCG (Good Corporate Governance) terhadap pertumbuhan laba.

Mursyidan \& Hanantijo (2016) menjelaskan apabila bank memiliki rasio ROA yang tinggi, laba yang diraih bank tersebut juga akan makin tinggi. Kinerja ROA yang meningkat mengindikasikan bank sanggup menggunakan aset yang dimilikinya secara optimal.

H4: Ada pengaruh dari earnings yang diproksikan dengan ROA (Return On Asset) terhadap pertumbuhan laba.

Rasio BOPO yang meningkat ditandai dengan penurunan pendapatan operasional bank yang diiringi oleh naiknya beban operasional bank. Meningkatnya rasio BOPO berarti banyaknya beban operasional yang ditanggung perbankan dibandingkan perolehan dari pendapatan operasionalnya, hal tersebut menjadikan pertumbuhan laba menurun (Taruna \& Setiawan, 2019).

H5: Ada pengaruh dari earnings yang diproksikan dengan BOPO (Biaya Operasional Pendapatan Operasional) terhadap pertumbuhan laba. 
Andini Estikarti Utami. Pengaruh Faktor Internal dan Eksternal terhadap Pertumbuhan Laba pada Bank Umum Swasta Nasional (BUSN) Non Devisa Periode 2014-2018.

Anggraeni (2013) mengutarakan bahwa CAR yaitu seluruh dana berupa modal yang dipakai guna mengantisipasi terjadinya risiko akibat dari investasi yang berisiko. Jika bank dapat menggunakan modalnya secara efisien, maka bank tersebut dapat memperoleh pertumbuhan laba seperti yang diharapkan (Rusdianto \& Pratama, 2017).

H6: Ada pengaruh dari capital yang diproksikan dengan CAR (Capital Adequacy Ratio) terhadap pertumbuhan laba.

Irwadi (2014) mengemukakan bahwa inflasi menyebabkan suku bunga meningkat yang menjadikan masyarakat cenderung menyimpan uangnya di bank jika memiliki kelebihan dana. Dana simpanan dari masyarakat ini dikenal dengan Dana Pihak Ketiga (DPK). Meningkatnya DPK pada suatu bank cenderung menyebabkan tingginya jumlah beban bunga yang ditanggung perbankan, sehingga akan mempengaruhi pada pertumbuhan laba yang diperoleh.

H7: Ada pengaruh dari faktor eksternal yang diproksikan dengan inflasi terhadap pertumbuhan laba.

\section{METODE PENELITIAN}

Penelitian ini menggunakan jenis penelitian kausal. Populasinya ialah BUSN non devisa yang tercatat dalam Otoritas Jasa Keuangan (OJK) selama periode 2014-2018. Penelitian ini memakai teknik purposive sampling, maka didapatkan sampel sejumlah 21 bank dengan menerapkan beberapa ketentuan. Penelitian ini memakai data kuantitatif dari sumber sekunder. Pengumpulan data dilakukan menggunakan cara dokumentasi berupa annual report dan laporan GCG melalui www.idx.co.id dan situs resmi perbankan terkait, serta data inflasi didapat dari www.bi.go.id. Ada pula data yang bersumber dari studi kepustakaan berupa artikel ilmiah dan literatur terkait topik penelitian.Teknik analisis yang digunakan antara lain uji asumsi klasik, analisis regresi linear berganda, uji t, uji f, dan koefisien determinasi. Berikut adalah bentuk model regresi linear berganda (8) yang akan diuji dalam penelitian ini.

$Y=\alpha+\beta_{1} X_{1}+\beta_{2} X_{2}+\beta_{3} X_{3}+\beta_{4} X_{4}+\beta_{5} X_{5}+\beta_{6} X_{6}+\beta_{7} X_{7}+e$

Keterangan:

Y : Pertumbuhan Laba

$\alpha \quad$ : Konstanta

$\beta_{1}, \beta_{2} \ldots \beta \mathrm{n} \quad$ : Koefisien regresi

$\mathrm{X}_{1} \quad$ : NPL

$\mathrm{X}_{2} \quad:$ LDR

$\mathrm{X}_{3} \quad:$ GCG

$\mathrm{X}_{4} \quad: \mathrm{ROA}$

$\mathrm{X}_{5} \quad: \mathrm{BOPO}$

$\mathrm{X}_{6} \quad:$ CAR

$\mathrm{X}_{7} \quad$ : Inflasi

e $\quad:$ Standard error atau residual

\section{HASIL DAN PEMBAHASAN}

\section{Hasil Transformasi Data dan Data Outlier}

Hasil dari uji normalitas menunjukkan nilai signifikansi senilai 0,000 yang lebih kecil dari 0,05 dan hasil uji screening juga diperoleh nilai yang sama untuk semua variabel, dengan artian data penelitian belum terdistribusi secara normal. Oleh karena itu, perlu dilakukan transformasi data pada semua variabel dengan melihat bentuk grafik histogramnya agar dapat memenuhi asumsi normalitas (Ghozali, 2018:34). Dikarenakan histogram berbentuk lonceng yang miring ke kiri (moderate positive skewness), maka transformasi data berupa SQRT (square root). Namun dengan adanya transformasi, data tersebut masih belum berdistribusi normal, maka diperlukan outlier untuk melihat data yang 
memiliki nilai ekstrim (Ghozali, 2018:40). Langkah selanjutnya yaitu membuang data outlier, sehingga jumlah data dalam penelitian ini menjadi 46.

\section{Hasil Uji Normalitas}

Perolehan nilai signifikansi dari uji K-S yaitu sebesar 0,096 yang mana nilainya lebih besar dari 0,05 yang memiliki arti data telah berdistribusi secara normal. Selain itu, grafik histogram pada gambar 2 mempunyai bentuk lonceng dengan keadaan seimbang antara kanan dan kiri serta gambar 3 dari normal probability plot mempunyai titik-titik yang menyebar dan mengikuti arah garis diagonal mengindikasikan data berdistribusi normal.

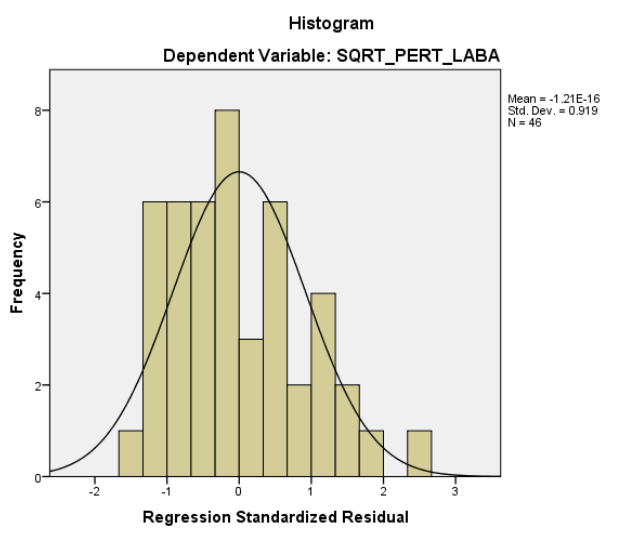

Sumber: Output SPSS (data diolah, 2020)

Gambar 2. HISTOGRAM

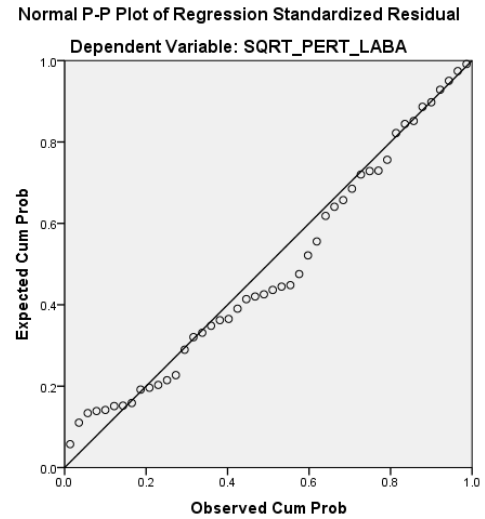

Sumber: Output SPSS (data diolah, 2020)

Gambar 3. NORMAL PROBABILITY PLOT

\section{Hasil Uji Multikolinearitas}

Dari hasil uji multikolinearitas, nilai tolerance dari seluruh variabel independen tidak kurang dari 0,10 , maka korelasi antar variabel independen tidak terjadi pada penelitian ini. Nilai VIF dari semua variabel independen memperoleh nilai lebih dari 10, artinya tidak ada gejala multikolinearitas dalam model regresi.

\section{Hasil Uji Heteroskedastisitas}

Hasil dari uji Glejser mengindikasikan seluruh variabel mempunyai nilai signifikansi di atas 0,05 yang artinya gejala heteroskedastisitas tidak muncul dalam penelitian ini.

\section{Hasil Uji Autokorelasi}

Dalam pengujian autokorelasi, digunakan uji Durbin-Watson dengan persamaan $\mathrm{du}<\mathrm{d}<4$-du. Sehingga, diperoleh nilai 1,8906 < 1,967 <2,1094 yang berarti tidak timbul indikasi autokorelasi. 
Andini Estikarti Utami. Pengaruh Faktor Internal dan Eksternal terhadap Pertumbuhan Laba pada Bank Umum Swasta Nasional (BUSN) Non Devisa Periode 2014-2018.

\section{Hasil Uji Regresi Linear Berganda}

Mengacu pada tabel 2 yang menyajikan hasil uji regresi linear berganda, diperoleh bentuk persamaan (9) seperti di bawah ini.

$\mathrm{Y}=0,095 \mathrm{LDR}+e$

Tabel 2.

HASIL UJI REGRESI LINEAR BERGANDA

\begin{tabular}{lcccc}
\hline \multicolumn{1}{c}{ Model } & \multicolumn{2}{c}{ Unstandardized Coefficients } & \multirow{2}{*}{ t } & Sig. \\
& B & Std. Error & & .788 \\
\hline 1 (Constant) & -.792 & 1.006 & -.295 & .769 \\
SQRT_NPL & -.021 & .071 & 4.149 & .000 \\
SQRT_LDR & .095 & .023 & .665 & .510 \\
SQRT_GCG & .341 & .513 & -.124 & .902 \\
SQRT_ROA & -.020 & .163 & .444 & .659 \\
SQRT_BOPO & .019 & .043 & -1.206 & .235 \\
SQRT_CAR & -.061 & .051 & .612 & .544 \\
SQRT_INFLASI & .058 & .095 & & \\
\hline
\end{tabular}

Sumber: Output SPSS (data diolah, 2020)

\section{Hasil Uji F}

Berdasarkan hasil pengujian secara simultan diperoleh nilai signifikansi sebesar 0,005 yang memiliki arti bahwa NPL, LDR, GCG, ROA, BOPO, CAR, dan inflasi secara bersama-sama berpengaruh pada pertumbuhan laba.

\section{Hasil Uji T}

Hasil pengujian secara parsial dapat dilihat melalui tabel 2. Variabel NPL, GCG, ROA, BOPO, CAR, dan inflasi memiliki nilai signifikansi di atas 0,05 yang menandakan tidak adanya pengaruh terhadap pertumbuhan laba. Sementara, LDR mempunyai nilai signifikansi $0,000<0,05$ dengan perolehan $t$ hitung sebesar 4,149 yang berarti LDR berdampak signifikan positif pada pertumbuhan laba.

\section{Hasil Uji Koefisien Determinasi}

Pengujian ini memakai nilai Adjusted $\mathrm{R}^{2}$ dengan perolehan sebesar 0,288 atau 28,8\%. Hal ini artinya variabel independen meliputi NPL, LDR, GCG, ROA, BOPO, CAR, dan inflasi mampu menerangkan variasi variabel dependen sebesar $28,8 \%$, sedangkan $71,2 \%$ dijelaskan oleh variabel lain yang tidak diasumsikan dalam model regresi.

\section{Pengaruh Risk Profile yang diproksikan dengan NPL (Non Performing Loan) terhadap Pertumbuhan Laba}

Hasil penelitian menunjukkan tidak ada pengaruh antara NPL dengan pertumbuhan laba. Kondisi demikian dapat terjadi karena nilai rata-rata NPL pada BUSN non devisa periode 2014-2018 sebesar 3,15 yang mengindikasikan bank dalam kategori sehat dan manajemen bank telah mengelola penyaluran kreditnya dengan baik. Selain itu, ketika bank masih memiliki dana cadangan yang cukup maka rasio kredit bermasalah masih bisa diatasi (Karim et al., 2018). Penelitian ini mempunyai kesamaan dengan Setiawan \& Hanryono (2016) yang mengatakan bahwa risiko kredit perbankan tidak berdampak langsung pada pertumbuhan laba dikarenakan kredit yang disalurkan kepada nasabah telah diasuransikan oleh bank, maka risiko kredit yang diproksikan dengan NPL belum tentu akan berpengaruh pada pertumbuhan laba. Hal ini sesuai dengan SE BI Nomor 12/ 35 /DPNP tanggal 23 Desember 2010 yang menyatakan bahwa adanya bancassurance, yaitu kerjasama pemasaran antara perusahaan asuransi dengan perbankan dalam rangka mendukung perkembangan pasar keuangan, meningkatkan penerapan manajemen risiko bank dan melindungi kepentingan nasabah. Asuransi tersebut dimaksudkan untuk kepentingan dan perlindungan kepada bank atas risiko terkait dengan produk atau jasa yang ditawarkan bank kepada nasabah.

Bank Artos Indonesia pada tahun 2016 memiliki tingkat rasio NPL sebesar 6,82 yang artinya bank tersebut dikategorikan cukup sehat. Namun dengan rasio NPL yang cukup besar, Bank Artos 
Indonesia masih bisa meraih pertumbuhan laba sebesar 121,31. Sedangkan, Prima Master Bank di tahun 2016 memiliki NPL 1,38 yang tergolong sangat sehat, akan tetapi bank tersebut mengalami penurunan pertumbuhan laba sebesar $-5,94$. Hal ini menjelaskan bahwa tinggi rendahnya rasio NPL tidak selalu berdampak pada pertumbuhan laba.

Implikasi teoritis dari hasil penelitian tidak sejalan dengan signaling theory yang menyatakan jika rasio NPL rendah, maka pertumbuhan laba akan meningkat yang ditandai dengan adanya sinyal positif melalui laporan keuangan yang dapat digunakan sebagai pertimbangan pengambilan keputusan (Lestari et al., 2015). Sedangkan, implikasi praktisnya ialah perbankan tetap harus menjaga rasio NPL dalam kategori sehat dan sebaiknya mempertimbangkan faktor-faktor lain yang dapat mempengaruhi pertumbuhan laba karena hasil penelitian menunjukkan pergerakan rasio NPL tidak berpengaruh terhadap pertumbuhan laba.

\section{Pengaruh Risk Profile yang diproksikan dengan LDR (Loan to Deposit Ratio) terhadap Pertumbuhan Laba}

Penelitian ini memiliki hasil LDR mempengaruhi pertumbuhan laba secara positif. Penelitian ini didukung oleh Pratito \& Puspitasari (2017) yang berpendapat apabila rasio LDR semakin tinggi maka akan meningkatkan pertumbuhan laba. Tingginya rasio LDR menjadikan laba bank ikut meningkat dengan asumsi penyaluran kredit dilakukan secara efektif. BUSN non devisa di tahun 2014-2018 memiliki rata-rata rasio LDR BUSN non devisa 2014-2018 sebesar 169,50 yang mana bank termasuk dalam kondisi sangat sehat. Hal ini artinya BUSN non devisa selama periode 2014-2018 memiliki kecukupan likuiditas untuk menjalankan bisnisnya dengan efisien dan dapat memenuhi kewajiban kepada kreditur yang telah jatuh tempo atau secara tiba-tiba melakukan penarikan.

Adapun data yang mendukung hasil penelitian ini, seperti pada tahun 2014 Bank Panin Syariah memiliki tingkat rasio LDR 498,86 dengan pertumbuhan laba yang meningkat sebesar 2,33. Rasio LDR tersebut tergolong cukup tinggi yang artinya Bank Panin Syariah termasuk dalam kategori tidak sehat karena terlalu banyak dana yang disalurkan dalam bentuk kredit, meskipun begitu peningkatan pertumbuhan laba masih dapat dicapai. Bank Syariah BRI pada tahun 2015 juga mengalami hal serupa dengan perolehan LDR 133,29 dan pertumbuhan laba yang meningkat sebesar 17,65. Dari data tersebut disimpulkan bahwa semakin tinggi rasio LDR suatu bank akan meningkatkan pertumbuhan laba.

Implikasi teoritisnya adalah signaling theory cocok dengan hasil penelitian. Tingginya rasio LDR mencerminkan sinyal baik (good news) karena menggambarkan tingkat likuiditas yang bagus, sehingga pertumbuhan laba juga akan ikut meningkat (Rusdianto \& Pratama, 2017). Sinyal tersebut dapat dilihat melalui laporan keuangan yang dipublikasikan perbankan dan dapat dijadikan sebagai pertimbangan pengambilan keputusan bagi pihak berkepentingan. Hasil penelitian ini dapat digunakan sebagai referensi bagi peneliti yang menemukan adanya pengaruh positif signifikan antara LDR dengan pertumbuhan laba. Sementara, implikasi praktisnya yakni perbankan khususnya BUSN non devisa harus meningkatkan dan menjaga rasio likuiditasnya karena besarnya kecukupan likuiditas pada bank mampu mempengaruhi adanya pertumbuhan laba perbankan.

\section{Pengaruh GCG (Good Corporate Governance) terhadap Pertumbuhan Laba}

Hasil penelitian menyatakan bahwa GCG tidak berpengaruh terhadap pertumbuhan laba. Kondisi seperti ini dapat terjadi karena GCG hanya merupakan proses internal manajemen bank dalam menangani masalah yang timbul dengan hati-hati dan profesional (Pracoyo \& Putriyanti, 2016). Dalam hal ini GCG berfungsi untuk mengelola manajemen supaya profesional dan prudensial yang menjadikan citra perusahaan perbankan dikenal baik oleh nasabah yang dapat membawa dampak jangka panjang. Rendahnya perolehan nilai komposit GCG oleh perbankan belum tentu berimbas pada pertumbuhan laba, maka dari itu perbankan sebaiknya juga memperhatikan kinerja keuangan lainnya dalam meningkatkan perolehan pertumbuhan laba. Selain itu, menurut Mursyidan \& Hanantijo (2016) perhitungan nilai komposit yang mencakup 11 faktor tidak didasari pada kegiatan operasional bank yang memengaruhi pertumbuhan laba seperti yang dijelaskan pada SE BI No. 
Andini Estikarti Utami. Pengaruh Faktor Internal dan Eksternal terhadap Pertumbuhan Laba pada Bank Umum Swasta Nasional (BUSN) Non Devisa Periode 2014-2018.

15/15/DPNP tanggal 29 April 2013. Sebagai contoh faktor pertama dan kedua, yaitu pelaksanaan tugas dan tanggung jawab dewan komisaris dan direksi tidak berpengaruh pada pertumbuhan laba karena dewan komisaris dan direksi berfungsi untuk mengawasi kegiatan suatu perusahaan atau organisasi.

Bank Victoria Internasional, Tbk tahun 2014 menunjukkan data yang mendukung hasil penelitian ini dengan perolehan nilai komposit GCG yang kecil yaitu 1 dan diiringi adanya penurunan pertumbuhan laba -0,57. Sedangkan, Bank Artos Indonesia di tahun 2016 mendapati nilai komposit GCG sebesar 3 dan pertumbuhan laba meningkat sebesar 121,31. Sehingga, dari data tersebut dapat disimpulkan bahwa semakin kecil atau besar nilai komposit GCG dari self assesment tidak selalu berdampak pada pertumbuhan laba.

Agency theory tidak mendukung hasil penelitian ini yang menjelaskan tata kelola perusahaan dapat mengatasi adanya konflik kepentingan antara pemilik (principal) dan pengelola perusahaan (agent). Sementara, implikasi praktisnya pertumbuhan laba tidak perlu ditingkatkan maupun diturunkan melalui GCG dengan nilai komposit dan sebaiknya mempertimbangkan untuk menggunakan variabel atau pengukuran lain dari GCG yang dapat berpengaruh pada pertumbuhan laba perbankan.

\section{Pengaruh Earnings yang diproksikan dengan ROA (Return On Asset) terhadap Pertumbuhan Laba}

Penelitian ini menunjukkan hasil tidak ada pengaruh ROA pada pertumbuhan laba. Keadaan ini dapat terjadi karena terdapat beberapa perusahaan perbankan yang ROAnya berada di bawah rata-rata $(0,58)$, seperti Bank Panin Syariah tahun 2017 dengan rasio ROA sebesar -11,21 yang mana nilai tersebut tergolong rendah dan termasuk dalam kategori tidak sehat. Penelitian ini didukung oleh Dewi \& Mukhlis (2012) yang berpendapat apabila kurang optimalnya perbankan dalam mengelola aset yang dimiliki dapat menjadikan keuntungan yang diterima bank tersebut juga kurang optimal. Perbankan dalam menjalankan kegiatan operasionalnya memiliki memiliki aset tetap dan aset lancar. Saat ini bank lebih cenderung mementingkan aset lancar daripada aset tetap yang dimilikinya karena fokus pada layanan digital money atau transaksi yang melibatkan penggunaan jaringan komputer, sehingga perbankan tidak perlu menyiapkan kantor atau ATM dalam jumlah banyak.

Adapun data yang mendukung penelitian ini, yaitu Bank Artos Indonesia di tahun 2016 memiliki rasio ROA yang tergolong rendah -4,98 dengan peningkatan pertumbuhan laba mencapai 121,31. Sementara, Bank Jasa Jakarta tahun 2017 meraih rasio ROA sebesar 2,54 namun pertumbuhan labanya mengalami penurunan $-0,08$. Oleh karena itu, besar kecilnya rasio ROA belum tentu akan mempengaruhi naik turunnya pertumbuhan laba.

Implikasi teoritis dari hasil penelitian tidak sejalan dengan signaling theory yang mengungkapkan kinerja ROA yang meningkat menggambarkan kondisi bahwa bank mampu mengoptimalkan aset yang dimilikinya, sehingga akan meningkatkan pertumbuhan laba yang ditandai dengan adanya sinyal positif melalui laporan keuangan yang dipublikasikan perbankan (Mursyidan \& Hanantijo, 2016). Sementara, implikasi praktisnya adalah perbankan tetap harus menjaga rasio ROA dalam kondisi yang sehat meskipun hal tersebut tidak berpengaruh pada pertumbuhan laba. Alternatif yang bisa digunakan ialah memakai variabel lain guna menemukan pengaruh dalam pertumbuhan laba perbankan.

\section{Pengaruh Earnings yang diproksikan dengan BOPO (Biaya Operasional Pendapatan Operasional) terhadap Pertumbuhan Laba}

Hasil dari penelitian ini yaitu tidak ada pengaruh antara BOPO dengan pertumbuhan laba. Hal tersebut dapat terjadi dikarenakan perbankan belum optimal dalam menjalankan kegiatan operasionalnya dengan tingginya pendapatan yang diperoleh serta tidak mampu menekan biaya operasional yang ditanggung perbankan (Rafiqah et al., 2017). Selain itu, terdapat perbankan dengan rasio BOPO melebihi ketentuan SE BI No.6/23/DPNP tentang Sistem Penilaian Tingkat Kesehatan Bank Umum yaitu di atas $97 \%$ yang dikategorikan dalam kondisi tidak sehat, seperti Bank Artos Indonesia di tahun 2015 dan 2016 rasio BOPOnya mencapai 101,31 dan 209,75 dengan komposisi 
beban operasional yang ditanggung Bank Artos Indonesia lebih besar dibandingkan pendapatan operasional yang diterima di tahun tersebut.

Implikasi teoritis dari penelitian ini tidak cocok dengan signaling theory yang mengungkapkan bahwa rendahnya rasio BOPO mengindikasikan pendapatan operasional yang diperoleh bank lebih besar dibandingkan beban operasional yang harus ditanggung bank, maka pertumbuhan laba dapat meningkat (Taruna \& Setiawan, 2019). Dalam hal ini, rasio BOPO yang rendah menandakan adanya sinyal yang baik (good news) dan dapat digunakan sebagai pertimbangan pengambilan keputusan di masa yang akan datang. Implikasi praktisnya perbankan wajib menjaga rasio BOPO dalam keadaan sehat agar kegiatan operasional dapat berjalan dengan optimal dan sebaiknya menggunakan variabel lain yang dapat memiliki pengaruh pada pertumbuhan laba perbankan.

\section{Pengaruh Capital yang diproksikan dengan CAR (Capital Adequacy Ratio) terhadap Pertumbuhan Laba}

Penelitian ini memiliki hasil CAR tidak memiliki pengaruh pada pertumbuhan laba perbankan. Rusdianto \& Pratama (2017) mengungkapkan hal tersebut dapat terjadi ketika modal bank hanya untuk memenuhi ketentuan dari Bank Indonesia, maka pergerakan rasio CAR tidak akan berpengaruh pada pertumbuhan laba yang diperoleh bank. Seiring dengan hal tersebut, bank belum mengoptimalkan modalnya untuk kegiatan yang menghasilkan keuntungan karena perlu memperkirakan peningkatan ATMR sehingga menjadikan CAR bukan merupakan faktor yang signifikan pada pertumbuhan laba.

Data yang mendukung hasil penelitian ini yaitu Bank Kesejahteraan Ekonomi di tahun 2014 memiliki rasio CAR 13,74 yang termasuk dalam kategori sangat sehat, tetapi perolehan pertumbuhan labanya menurun sebesar -1,31. Di tahun 2017 Bank Panin Syariah juga mendapati hal yang sama dimana perolehan CAR 11,51 diikuti dengan pertumbuhan laba yang menurun sebesar -50,58. Menurut data yang telah disajikan, besar kecilnya perolehan CAR suatu bank belum tentu mempengaruhi pertumbuhan laba.

Implikasi teoritis dari hasil penelitian tidak mendukung signaling theory yang mengungkapkan jika modal yang dimiliki perbankan dapat digunakan secara efisien, maka bank dapat memperoleh laba seperti yang diharapkan (Rusdianto \& Pratama, 2017). Rendahnya nilai CAR mengindikasikan adanya sinyal yang baik (good news) sehingga dapat digunakan oleh pihak yang berkepentingan untuk pertimbangan pengambilan keputusan. Implikasi praktisnya perbankan harus tetap mengelola CAR dalam kondisi yang sehat serta mempertimbangkan penggunaan variabel lain yang dapat mempengaruhi pertumbuhan laba perbankan.

\section{Pengaruh Faktor Eksternal yang diproksikan dengan Inflasi terhadap Pertumbuhan Laba}

Hasil penelitian menunjukkan bahwa inflasi tidak berpengaruh pada pertumbuhan laba. Setiawan \& Hanryono (2016) memiliki kesamaan dengan penelitian ini yang berpendapat jika inflasi terjadi, maka harga-harga cenderung naik secara umum dan berdampak pada meningkatnya biaya operasional perusahaan. Akan tetapi, tingkat inflasi yang tinggi juga berpotensi menyebabkan naiknya tingkat suku bunga sehingga membuat masyarakat tertarik untuk meningkatkan simpanannya di bank. Meningkatnya Dana Pihak Ketiga (DPK) pada perbankan dapat mengakibatkan tingginya jumlah beban bunga yang ditanggung, sehingga pertumbuhan laba tidak terjadi pada bank tersebut.

Di tahun 2014 dengan tingkat inflasi moderat senilai 8,34 Bank Panin Syariah dan Bank Royal Indonesia masih dapat meraih pertumbuhan laba sebesar 2,33 dan 1,02. Sedangkan, Prima Master Bank pada tahun 2016 mendapati penurunan pertumbuhan laba sebesar -5,94 dengan tingkat inflasi yang rendah senilai 3,02. Sejalan dengan data tersebut, maka kenaikan dan penurunan inflasi suatu negara tidak akan mempengaruhi pertumbuhan laba perusahaan perbankan.

Implikasi praktis dari penelitian ini adalah perbankan tidak perlu meningkatkan atau menurunkan pertumbuhan laba yang berhubungan dengan inflasi karena tidak ada pengaruhnya pada pertumbuhan 
Andini Estikarti Utami. Pengaruh Faktor Internal dan Eksternal terhadap Pertumbuhan Laba pada Bank Umum Swasta Nasional (BUSN) Non Devisa Periode 2014-2018.

laba. Alternatif yang dapat dilakukan yaitu menggunakan variabel lain yang dapat mempengaruhi pertumbuhan laba perbankan.

\section{KESIMPULAN}

Hasil penelitian ini menerangkan adanya pengaruh signifikan positif pada risk profile yang diproksikan dengan LDR pada pertumbuhan laba. Sementara, terdapat variabel yang tidak berpengaruh pada pertumbuhan laba antara lain NPL, GCG, ROA, BOPO, CAR, dan inflasi. Oleh karena itu, perbankan di masa mendatang harapannya dapat meningkatkan dan menjaga rasio likuiditas karena besarnya kecukupan likuiditas pada bank dapat digunakan untuk menjalankan kegiatan operasional secara efisien serta dapat memenuhi kewajiban kepada kreditur yang telah jatuh tempo atau secara tiba-tiba melakukan penarikan. Hal tersebut mampu mempengaruhi adanya pertumbuhan laba perbankan.

Dalam penelitian ini terdapat keterbatasan, seperti komponen GCG yang dirasa masih kurang karena tidak semua BUSN non devisa memiliki penilaian mandiri (self assessment) sehingga sampel penelitian yang dipakai hanya sebanyak 21 BUSN non devisa yang terdaftar di OJK selama periode 2014-2018. Oleh karena itu, peneliti selanjutnya yang berminat melakukan penelitian lebih lanjut mengenai pertumbuhan laba perbankan disarankan untuk menambah variabel lain seperti KAP (Kualitas Aktiva Produktif), PDN (Posisi Devisa Neto), BI Rate, CKPN (Cadangan Kerugian Penurunan Nilai), IRR (Interest Risk Ratio), NIM (Net Interest Margin) serta memperpanjang tahun penelitian supaya hasil pengolahan data dapat dimanfaatkan dengan optimal.

\section{DAFTAR PUSTAKA}

Akhyar, C., . M., . A., \& Syamni, G. (2018). Profit Growth in Indonesian Sharia Bank: the Impact of RGEC. International Journal of Engineering \& Technology, 7(3.30), 587-591. https://doi.org/10.14419/ijet.v7i3.30.18437

Alfin, N. A., \& Hartono, U. (2018). Pengaruh Faktor Internal dan Makroekonomi Terhadap Risiko Kredit Pada Bank BUSN Devisa Periode 2012-2016. Jurnal Ilmu Manajemen (JIM), 6(3), 73 83. Retrieved from https://jurnalmahasiswa.unesa.ac.id/index.php/jim/article/view/23825

Anggraeni, F. (2013). Pengaruh CAR, NIM, KAP, LDR, dan Pengaruh CAR, NIM, KAP, LDR, dan Inflasi Terhadap Pertumbuhan Laba Pada Bank Umum Swasta Nasional Devisa Yang Terdaftar di BEI Periode 2008 - 2013. Jurusan Akuntansi Fakultas Universitas Pandanaran Semarang, 1(1), 1-22. Retrieved from https://jurnal.unpand.ac.id/index.php/AKS/article/view/193

Bank Indonesia. (2001). Surat Edaran Bank Indonesia Nomor 3/30/DPNP tanggal 14 Desember 2001. Retrieved from www.bi.go.id

Bank Indonesia. (2004). Surat Edaran Bank Indonesia No.6/23/DPNP tentang Sistem Penilaian Tingkat Kesehatan Bank Umum. Retrieved May 27, 2020, from https://www.bi.go.id/id/peraturan/perbankan/pages/ketentuan perbankan.aspx

Bank Indonesia. (2010). Surat Edaran Bank Indonesia Nomor 12/ 35 /DPNP tanggal 23 Desember 2010 tentang Penerapan Manajemen Risiko pada Bank yang Melakukan Aktivitas Kerjasama Pemasaran dengan Perusahaan Asuransi (Bancassurance). Retrieved May 27, 2020, from https://www.bi.go.id/id/peraturan/perbankan/Pages/se_123510.aspx

Bank Indonesia. (2011). Lampiran Surat Edaran Bank Indonesia Nomor 13/24/DPNP tanggal 25 Oktober 2011. Retrieved from www.bi.go.id

Bank Indonesia. (2011). SE No.13/24/DPNP/2011. Retrieved June 18, 2020, from https://www.bi.go.id/id/peraturan/perbankan/Pages/SE No.13_24_DPNP_2011.aspx 
Bank Indonesia. (2013). Surat Edaran Bank Indonesia No. 15/15/DPNP tanggal 29 April 2013 tentang Pelaksanaan Good Corporate Governance bagi Bank Umum. Retrieved from www.bi.go.id

Bank Indonesia. (2019). Laporan Inflasi. Retrieved from https://www.bi.go.id/id/moneter/inflasi/data/Default.aspx

Bursa Efek Indonesia. (2019). Laporan Keuangan Tahunan. Retrieved from idx.co.id

Dewi, D. E. K., \& Mukhlis, I. (2012). Pengaruh CAR, ROA, NPM dan LDR Terhadap Pertumbuhan Laba Bank (Studi Kasus PT. Bank Mandiri, Tbk). Jurnal Ekonomi \& Studi Pembangunan, 4(1), $61-72$.

Diah, S. R. (2016). Laba Perbankan Turun di 2015, Apa Penyebabnya? Retrieved October 15, 2019, from https://money.kompas.com/read/2016/02/04/133036926/Laba.Perbankan.Turun.di.2015.Apa.Pe nyebabnya

Fadila, I. (2016). Bank Swasta Masih Tertekan. Retrieved October 15, 2019, from https://banten.bisnis.com/read/20160520/446/549543/bank-swasta-masih-tertekan

Fahmi, I. (2015). Manajemen Perbankan: Konvensional dan Syariah. Jakarta: Mitra Wacana Media.

Ghozali, I. (2018). Aplikasi Analisis Multivariate dengan Program IBM SPSS 25 (9th ed.). Semarang: Badan Penerbit Universitas Diponegoro.

Gumanti, T. A. (2017). Keuangan Korporat: Tinjauan Teori dan Bukti Empiris. Jakarta: Mitra Wacana Media.

Hanafi, J., \& Breliastiti, R. (2016). Peran Mekanisme Good Corporate Governance Dalam Mencegah Perusahaan Mengalami Financial Distress. Jurnal Online Insan Akuntan, 1(1), 195-220. Retrieved from http://ejournal-binainsani.ac.id/index.php/JOIA/article/view/10

Irma, Hadiwidjaja, R. D., \& Widiastuti, Y. (2016). Assessing the Effect of Bank Performance on Profit Growth Using RGEC Approach. Organization Development Journal, 5(3), 87-101. https://doi.org/http://dx.doi.org/10.1108/17506200710779521

Jatmiko, A. (2018). Laba Emiten Sektor Keuangan dan Konsumer Tertinggi Pada 2017. Retrieved October 23, 2019, from https://investasi.kontan.co.id/news/laba-emiten-sektor-keuangan-dankonsumer-tertinggi-pada-2017

Karim, A., Rachmawati, W., \& Widyaswati, R. (2018). The Analysis of Sharia Banks Soundness Level Using Rgec Method. Economics \& Business Solutions Journal, 1(1), 1-12.

Krisnawati, D. A., \& Chabachib, M. (2014). Analisis Faktor Penentu Profitabilitas Bank di Indonesia Dengan Metode Risk Based Bank Rating (Studi Pada Bank-Bank Umum Go Public di Indonesia Periode 2008-2013). Diponegoro Journal of Management, 3(4), 1-14. Retrieved from http://ejournal-s1.undip.ac.id/index.php/dbr

Lestari, T., Andini, R., \& Raharjo, K. (2015). Dampak Rasio CAR, NPL, NPM, ROA, LDR, IRR, dan Ukuran Perusahaan Dalam Memprediksi Pertumbuhan Laba pada Perusahaan Sektor Perbankan yang Go Publik di BEI Periode Periode Tahun 2009-2013. Jurnal Ilmiah Mahasiswa S1 Akuntansi Universitas Pandanaran, 1(1), 1-24. Retrieved from https://jurnal.unpand.ac.id/index.php/AKS/article/view/202

Lubis, A. (2013). Pengaruh Tingkat Kesehatan Bank Terhadap Pertumbuhan Laba Pada BPR di 
Andini Estikarti Utami. Pengaruh Faktor Internal dan Eksternal terhadap Pertumbuhan Laba pada Bank Umum Swasta Nasional (BUSN) Non Devisa Periode 2014-2018.

Indonesia. Jurnal Ekonomi Dan Keuangan, 4(1), 27-37. Retrieved from https://www.mendeley.com/catalogue/pengaruh-tingkat-kesehatan-bank-terhadappertumbuhan-laba-pada-bpr-di-indonesia-2/

Mursyidan, P., \& Hanantijo, M. D. (2016). Pengaruh Tingkat Kesehatan Bank Terhadap Pertumbuhan Laba (Studi Kasus Pada Bank yang Menjadi Entitas Utama dalam Konglomerasi Keuangan di Indonesia Periode 2012-2016). Perbanas Review, 2(2), 112-129. Retrieved from https://digilib.perbanas.id/index.php?p=show_detail\&id=31596\&keywords=

Otoritas Jasa Keuangan. (2019). Statistik Perbankan Indonesia. Retrieved from https://www.ojk.go.id/id/kanal/perbankan/data-dan-statistik/statistik-perbankanindonesia/default.aspx

Pracoyo, A., \& Putriyanti, D. (2016). Assessment of Bank Health Level towards Profit Growth. Jurnal Ilmu Manajemen \& Ekonomika, 8(2), 133-149. https://doi.org/10.35384/jime.v8i2.15

Pratito, D. W., \& Puspitasari, D. (2017). Analisis Pengaruh Kebijakan Giro Wajib Minimum (GWM), Posisi Devisa Netto (PDN), Loan To Deposit Ratio (LDR), Cadangan Kerugian Penurunan Nilai (CKPN), dan Suku Bunga SBI Terhadap Perubahan Laba. Jurnal Dinamika Sosial Budaya, 17(2), 228-241. $\quad$ Retrieved http://journals.usm.ac.id/index.php/jdsb/article/view/488

Purwoko, D., \& Sudiyatno, B. (2013). Faktor-faktor Yang Mempengaruhi Kinerja Bank (Studi Empirik Pada Industri Perbankan di Bursa Efek Indonesia). Journal of Business Economics and Management, 20(1), 25-39. $\quad$ Retrieved from https://www.unisbank.ac.id/ojs/index.php/fe3/article/view/2344

Rafiqah, N., Respati, N. W., \& Safrida, L. (2017). Pengaruh Non Performing Loan, Capital Adequacy Ratio, Loan to Deposit Ratio, Net Profit Margin, dan BOPO Terhadap Pertumbuhan Laba. Prosiding Seminar Nasional ASBIS, 2(1), 367-375. https://doi.org/ISSN 2541-6014

Rusdianto, \& Pratama, D. P. (2017). The Effect of Variable Risk Profile, Earnings, And Capital Against Growth of Banking Profit Registered At Indonesia Stock Exchange. International Journal of Quantitative Economics and Applied Management Research, 4(3), 40-59. Retrieved from http://ijbemr.com/wp-content/uploads/2017/09/THE-EFFECT-OF-VARIABLE-RISKPROFILE-EARNINGS-AND-CAPITAL-AGAINST-GROWTH-OF-BANKING-PROFITREGISTERED-AT-INDONESIA-STOCK-EXCHANGE.pdf

Setiawan, D. I., \& Hanryono. (2016). Analisis Pengaruh Kinerja Keuangan Bank, Tingkat Inflasi dan BI Rate Terhadap Pertumbuhan Laba (Studi Pada Bank Swasta Devisa Yang Terdaftar Pada Bursa Efek Indonesia Periode 2009-2013). Journal of Accounting and Business Studies, 1(1), 21-37. Retrieved from https://journal.ithb.ac.id/jabs/article/view/113

Sukirno, S. (2011). Makroekonomi Teori Pengantar (3rd ed.). Jakarta: PT RajaGrafindo Persada.

Suryani, Y., \& Habibie, A. (2017). Analisis Pengaruh Rasio - Rasio Risk Based Bank Rating Terhadap Pertumbuhan Laba Pada Perusahaan Perbankan Yang Terdaftar di BEI. Kitabah: Jurnal Akuntansi Dan Keuangan Syariah, 1(1), 1-21. Retrieved from http://jurnal.uinsu.ac.id/index.php/JAKS/article/view/816

Taruna, R. D., \& Setiawan. (2019). Pengaruh Kinerja Keuangan Terhadap Pertumbuhan Laba Bank Umum di Indonesia. Jurnal Accounting Information System (AIMS), 2(1), 69-78. Retrieved from http://journal.stkom.ac.id/index.php/aims/article/view/62

Uran, V. E. A., \& Wuryani, E. (2019). Pengaruh Risk Profile, Earnings, dan Capital Terhadap 
Pertumbuhan Laba. Jurnal Mahasiswa Unesa Jurusan Akuntansi, 7(1). Retrieved from https://jurnalmahasiswa.unesa.ac.id/index.php/jurnal-akuntansi/article/view/27107

Widyaningrum, H. A. (2014). Analisis Tingkat Kesehatan Bank Dengan Menggunakan Metode RiskBased Bank Rating (RBBR) (Studi pada Bank yang Terdaftar di Bursa Efek Indonesia dalam IHSG Sub Sektor Perbankan Tahun 2012). Jurnal Administrasi Bisnis S1 Universitas Brawijaya, 9(2), 1-9. $\quad$ Retrieved from http://administrasibisnis.studentjournal.ub.ac.id/index.php/jab/article/view/420 